\title{
WATER QUALITY ASSESSMENT OF THE MONTENEGRIN PART OF THE LIM RIVER USING THE SERBIAN WATER QUALITY INDEX (SWQI)
}

\author{
Filip Vujovići ${ }^{1 *}$, Mladen Delić ${ }^{*}$ Darko Smolović* \\ " Master's student, University of Montenegro, Faculty of Philosophy, Department of \\ Geography, Nikšić, Montenegro
}

\begin{abstract}
The paper analyzes the water quality of the Montenegrin part of the Lim River using the Serbian Water Quality Index (SWQI) method. This method uses ten physical, chemical, and microbiological parameters (temperature, $\mathrm{pH}$ value, electrical conductivity, oxygen saturation, $\mathrm{BOD}_{5}$, suspended solids, total nitrogen oxides, orthophosphates, ammonium, coliform bacteria) and summarizes them in a water quality index number. Data from the Institute of Hydrometeorology and Seismology of Montenegro (IHMS) from the Annual Reports on Water Quality from 2010 to 2018 were used to assess water quality. The results of this research, according to SWQI, show that in the upper course of the Montenegrin part of the Lim, at the control stations Plav and Andrijevica, water has excellent quality. Downstream, passing through the urban areas of Berane and BijeloPolje at the control stations Skakavac, Zaton, BijeloPolje, Dobrakovo, the water quality enters the class of very good and good quality. The results of average SWQI values at all control stations for the research period of eight years indicate that the quality in the Montenegrin part of the Lim River can be classified as very good (87). The paper confirms the importance of the SWQI as a useful method for presenting water quality data despite its many advantages and disadvantages. In order to achieve relevant results and the actual ecological status of the river, it is necessary to apply the Water Quality Index (WQI), which includes inorganic parameters.
\end{abstract}

Keywords: SWQI, water quality, Montenegro, WQI, Lim

${ }^{1}$ Corresponding author: F. Vujović, master's student, University of Montenegro, Faculty of Philosophy, Department of Geography, Nikšić, Montenegro; e-mail: vujovicfilip@hotmail.com 


\section{Introduction}

Water quality has recently become a significant issue in managing international river basins, especially in Europe. The issue of river water quality is reflected in environmental, economic, technological, and demographic changes (Shmueli, 1999; Kowalkowskiet al., 2006; O'Connell, 2017; Babić et al., 2019).

Water quality plays a vital role in all aspects of human and ecosystem survival. All living and industrial activities are controlled by physical, chemical, biological, and microbiological conditions in rivers and underground aquifers (Jakovljević, 2012).

In recent years, river water quality analysis based on mathematical indices that include physical, chemical, biological, and microbiological parameters has become increasingly common. Authors from around the world use different Water Quality Indices (WQI) as indicators of river pollution (Bordalo et al., 2006; Lumb et al., 2006; Bharti \& Katyal, 2011;Jakovljević, 2012; Singh et al., 2013; Tyagi et al. et al., 2013; Ismail \&Robescu, 2017; Babić et al., 2019;Durlević, 2020;Doderović et al., 2020).

Various environmental departments or agencies develop many WQI methods: National Sanitary Foundation, British Columbia Water Quality Index, Oregon Water Quality Index, Malaysian Water Quality Index, Florida Water Quality Index, Columbia Water Quality Index, Canadian Water Quality Index, Taiwan Water Quality Index, Washington State Water Quality Index, French Water Quality Index, Serbian Water Quality Index (Jakovljević, 2012).

Serbian Water Quality Index (SWQI) is based on the basic method of the Water Quality Index. It was developed by theSerbian Environmental Protection Agency (SEPA). This method uses ten physical, chemical, and microbiological parameters (temperature, $\mathrm{pH}$ value, electrical conductivity, oxygen saturation, $\mathrm{BOD}_{5}$, suspended solids, total nitrogen oxides, orthophosphates, ammonium, coliform bacteria) and summarizes them in a water quality index number (SEPA; Jakovljević, 2012; Durlević, 2020).

The same indicator and classification for WQI developed by the Serbian Environmental Protection Agency (SEPA) were used and developed by the Agency for Nature and Environment Protection of Montenegro (ANEPM). In addition to the Agency for Nature and Environment Protection of Montenegro (ANEPM) in the territory of Montenegro, the SWQI method, which is based on the basic WQI method in the Adriatic Sea Basin, was applied by Doderović et al. (2021) to assess water quality in the Morača River basin. 


\section{Research Area}

The research area of our paper is the Montenegrin part of the Lim River (Figure 1). Lim belongs to the Danube basin and is the most important river in the hydrological sense in Montenegro. The river source is Lake Plav, although its headwaters include rivers Vruja and Grnčar, which form the Ljuča, the river that flows into Lake Plav. The Lim flows through Montenegro, Serbia, and Bosnia and Herzegovina. It is the largest tributary of Drina, both in terms of the amount of water and the area of the basin, and it flows into it at a somewhat lower place than Medjedja. Before Andrijevica, the Murinska River and Zlorečica flow into Lim on the left side and Djurička, Rženička, Velička, and Komaračarivers on the right. From Andrijevica to Berane, Kraštica, Trebička, Ševarinska and Bistrica flow into Lim on the left and Šekularska and Kaludjerskarivers on the right. From Berane to BijeloPolje, Brzava and Ljubovidja flow into Lim on the left and Dapsićka and Lješnica on the right. From BijeloPolje to Dobrakovo, BjelopoljskaLješnica flows on the left side and BjelopoljskaBistrica on the right. The total length of the stream is $219 \mathrm{~km}, 87 \mathrm{~km}$ of which flows through the territory of Montenegro. The area of the Lim River basin in Montenegro is 2,280 $\mathrm{km}^{2}$. The total area of the Lim River basin is $6,016 \mathrm{~km}^{2}$ (Institute for Hydrometeorology and Seismology of Montenegro (IHMS); Hrvačević, 2004; Burić, 2010; Radojičić, 2005, 2008, 2015).

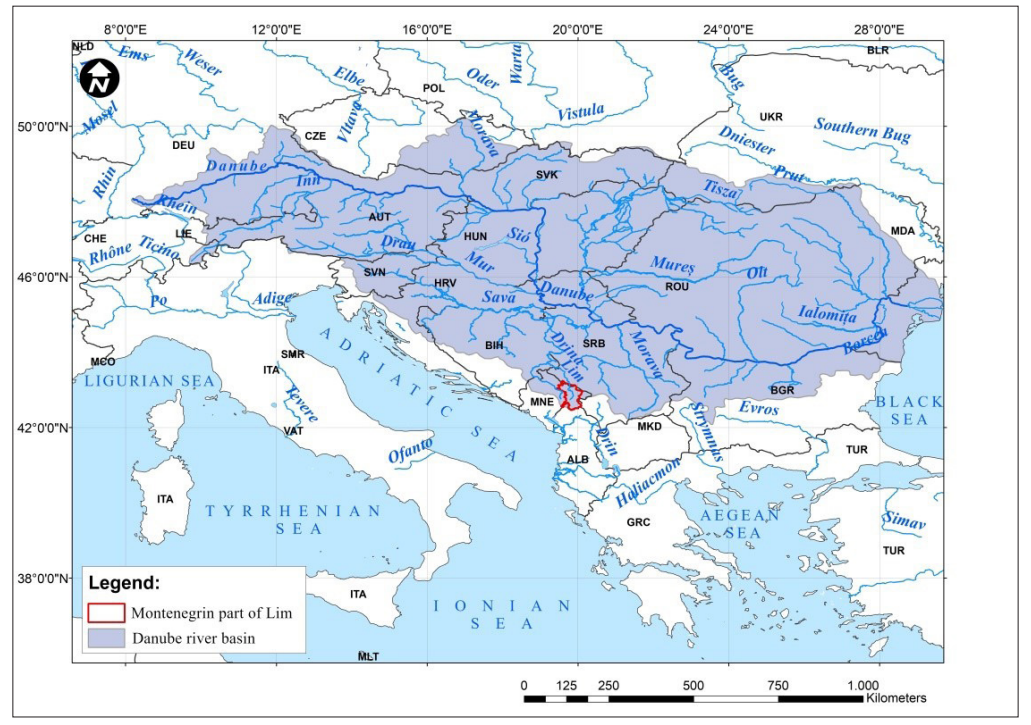

Figure 1. Position of the Montenegrin part of the Lim River 


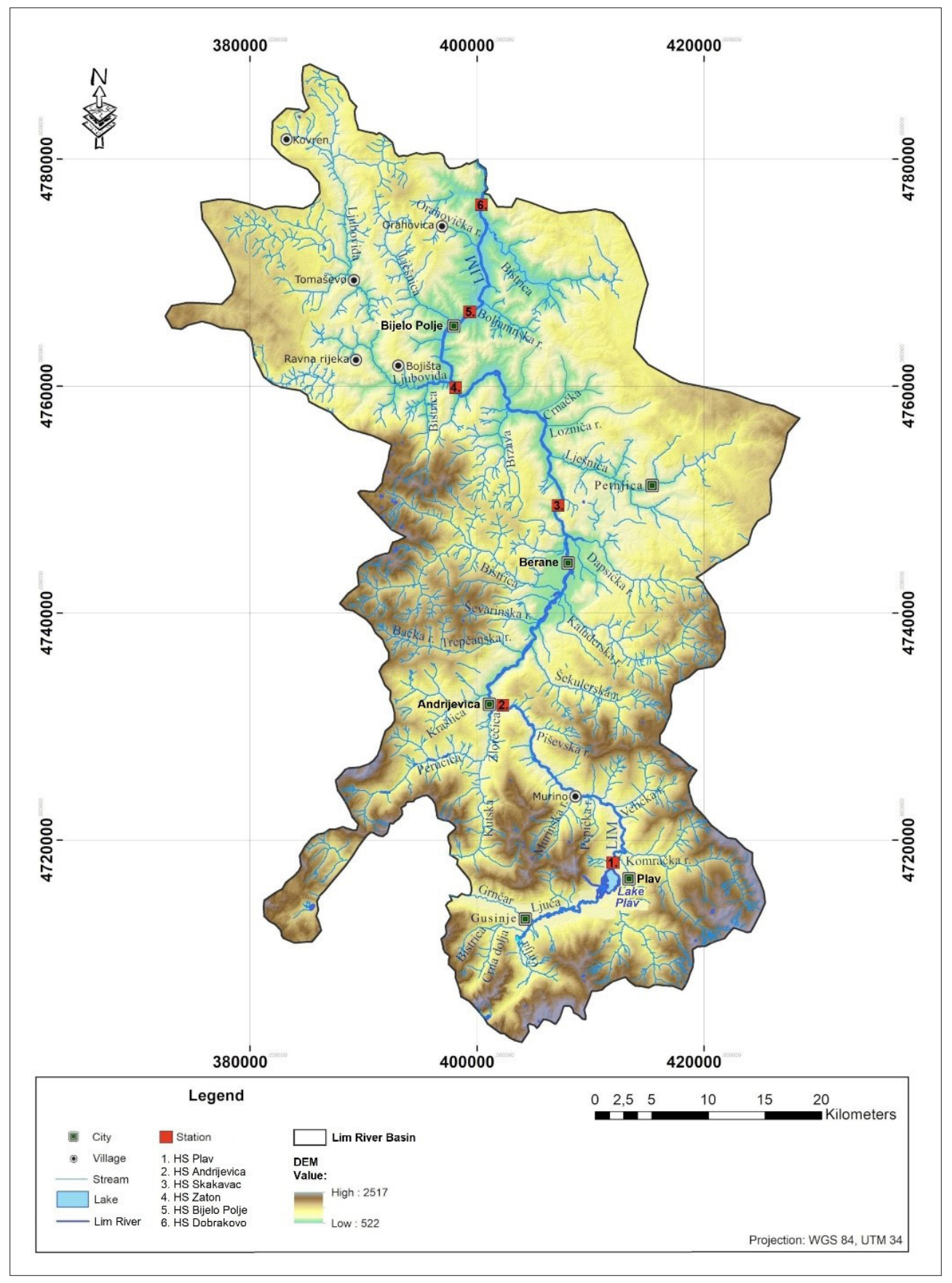

Figure 2. Map of the Montenegrin part of the Lim River with control stations 
According to the Köppenclassification, the area of theMontenegrin part of the Lim River valleyis characterized by the climate Cs"bx". In this subtype of the transitional type of the etesian climate, the influence of continentality on the precipitation regime is stronger. In the higher mountain areas covered by the study, mostly $1000 \mathrm{~m}$ above sea level, the climate is increasingly harsh. These are variants of moderately cold climates - Dfs"'bx", Dfs"'cx", Dfwbx", Dfwcx" (Burić et al., 2014).

Lim is characterized by anival-pluvial feeding regime. The natural water regime of Lim is uneven and does not meet the needs of users. The flows are minimal in the summer vegetation period of the year when the total needs of users are the greatest (Hrvačević, 2004; Burić, 2010).

The expanded Montenegrin part of the Lim River valley enabled urban development (Plav, Andrijevica,Berane, and BijeloPolje). In the middle of the $20^{\text {th }}$ century, the water quality in the Montenegrin part of Lim River was endangered by the process of urbanization, industrialization, agriculture, construction of traffic infrastructure, unregulated landfills, and wastewater.The north and northeast of Montenegro and this area have been experiencing depopulation and economic stagnation for the last three decades. However, today we have many generalpressures (households, production and consumption of all forms of energy in stationary or mobile sources, industry, various stationary and mobile activities, technological waste) that threaten this river. In addition to physical pollution, chemical contamination is nowhere less important, mainly due to anthropogenic activity (nitrates, nitrites and ammonia can be found in increasing quantities).

\section{Methodology and Data}

Data from the Institute of Hydrometeorology and Seismology of Montenegro (IHMS) from the Annual Reports on Water Quality ${ }^{2}$ were used to assess water quality. Data from six water quality control stations were processed: Plav, Andrijevica, Skakavac, Zaton, BijeloPolje, Dobrakovo (Figure 2) from 2010 to 2018 in Montenegro.

In order to calculate water quality, the Serbian Water Quality Index (SWQI) method was used. The Serbian Water Quality Index is based on the primary method of the Water Quality Index and was developed by the Serbian Environmental Protection Agency (SEPA; Jakovljević, 2012; Durlević, 2020).

2 http://www.meteo.co.me/page.php?id=57 
The Water Quality Index (WQI) method combines standardized values (qi) of ten parameters, which specify the properties of surface waters to calculate a unique index value (Kankal et al., 2012). This method uses ten physical, chemical, and microbiological parameters (temperature, $\mathrm{pH}$ value, electrical conductivity, oxygen saturation, $\mathrm{BOD}_{5}$, suspended solids, total nitrogen oxides, orthophosphates, ammonium, coliform bacteria) and summarizes them in a water quality index number. The impact of the ten listed physical, chemical, and microbiological parameters is not the same. Therefore, each has an assigned weight factor and an estimate of the number of points contributing to the water quality threat. By adding the products qi and wi, we come to the value of index 100 as the ideal sum of the values of all parameters (Summary of Oregon Water Quality Index Report, 1996-2005; Khan et al., 2005; Lumb et al., 2006; Veljković et al., 2008; Milijašević Joksimović et al., 2018; Breabăn et al., 2012; Babić et al., 2019).

The number and type of parameters and their weighting coefficients can vary (be adjusted) according to local or regional conditions (Hurley et al., 2012; Garcia et al., 2018). In case we do not have the value of a parameter, the value of the arithmetically calculated WQI is corrected by multiplying the index by the value $1 / k$, where $k$ is the sum of the arithmetically calculated weight factors of the available parameters (Veljković et al., 2008).

The arithmetic sequence for the Serbian Water Quality Index (SWQI) is calculated according to the following formula:

$$
S W Q I=1 / 100\left(\sum_{i=1}^{10} q_{i} \times w_{i}\right)
$$

whereSWQI is the water quality index and the number on a continuous scale from 0 to $100, \boldsymbol{q}_{i}$ - water quality of the appropriate parameter, $\boldsymbol{w}_{i}$ weight prescribed by the appropriate parameter (Veljković et al., 2008).

The final calculation of the SWQI value was performed using a calculator available on the website of the Serbian Environmental Protection Agency (SEPA) ${ }^{3}$. According to the SEPA recommendations, the total nitrogen oxide parameter can be replaced with a set of parameters Nitrates + Nitrites.

${ }^{3} \mathrm{http}: / /$ www.sepa.gov.rs/index.php?menu=46\&id=8012\&akcija=showExternal 
Table 1. Classification of surface water quality by the Serbian Water Quality Index (SWQI) method

\begin{tabular}{|c|r|r|}
\hline Water quality & Class intervals & Color symbol \\
\hline Excellent & $90-100$ & \\
\hline Very good & $84-89$ & \\
\hline Good & $72-83$ & \\
\hline Bad & $39-71$ & \\
\hline Very bad & $0-38$ & \\
\hline
\end{tabular}

Source: www.sepa.gov.rs

The classification of surface water values according to the SWQI method is divided into the following qualityclasses: very bad (0-38), bad (39-71), good (72-83), very good (84-89), excellent (90-100) (SEPA).

\section{Results}

The results of the research presented in Table 2 show the calculated annual and average values of the Serbian Water Quality Index (SWQI) at six control stations at the Montenegrin part of the Lim River for the period from 2010 to 2018.

The water quality at the Plav control station was classified as excellent $(2010,2011,2012,2013,2015,2016,2018)$ and very good $(2014,2017)$. Values ranged from the lowest 85 (2017) to the highest $95(2010,2016)$. According to the average SWQI results during the entire research period, water quality at the Plav station can be classified as excellent (91).

According to the average SWQI results during the entire research period, water quality at the Andrijevica station can be classified as excellent (90). Excellent water quality at this control station was not recorded in 2012, 2014, and 2017. Values ranged from the lowest 81 (2014) to the highest 94 (2018).

The water quality at the Skakavac control station was classified as very good $(2011,2012,2014,2015,2017,2018)$, good $(2013,2016)$, and excellent (2010). Values ranged from the lowest 80 (2016) to the highest 91 (2010). According to the average SWQI results during the entire research period, water quality at the Skakavac station can be classified as very good (86).

The water quality at the Zaton control station was classified as very good $(2010,2011,2014,2015,2017,2018)$, excellent $(2012,2013)$, good (2016). 
Values ranged from the lowest 82 (2016) to the highest 91 (2013). According to the average SWQI results during the entire research period, water quality at the Zaton station can be classified as very good (87).

The water quality at the BijeloPolje control station was classified as very $\operatorname{good}(2010,2013,2015,2018)$ and $\operatorname{good}(2011,2012,2014,2016,2017)$. Values ranged from the lowest $70(2011)$ to the highest $89(2013,2018)$. According to the average SWQI results during the entire research period, water quality at the BijeloPolje station can be classified as very good (84).

The water quality at the Dobrakovo control station was classified as good $(2010,2011,2012,2014,2015,2016)$ and very good $(2013,2017,2018)$. Values ranged from the lowest 73 (2014) to the highest 88 (2013, 2018). According to the average SWQI results during the entire research period, the water quality at the Dobrakovo station can be classified as good (81).

According to the average SWQI values during the entire research period at all control stations, the water quality was classified as very good (2010, 2011, 2012, 2013, 2015, 2016, 2017), excellent (2018), and good (2014). Values ranged from the lowest 83 (2014) to the highest 90 (2018). According to the average SWQI during the entire research period, the water quality at all control stations can be classified as very good (87).

Table 2. Average annual SWQI at control stations in the Montenegrin part of the Lim River

\begin{tabular}{|l|c|c|c|c|c|c|c|c|c|c|}
\hline CS & $\mathbf{2 0 1 0}$ & $\mathbf{2 0 1 1}$ & $\mathbf{2 0 1 2}$ & $\mathbf{2 0 1 3}$ & $\mathbf{2 0 1 4}$ & $\mathbf{2 0 1 5}$ & $\mathbf{2 0 1 6}$ & $\mathbf{2 0 1 7}$ & $\mathbf{2 0 1 8}$ & Average \\
\hline Plav & 95 & 91 & 92 & 92 & 88 & 92 & 95 & 85 & 91 & 91 \\
\hline Andrijevica & 93 & 90 & 89 & 93 & 81 & 91 & 91 & 88 & 94 & 90 \\
\hline Skakavac & 91 & 87 & 87 & 83 & 86 & 86 & 80 & 85 & 89 & 86 \\
\hline Zaton & 89 & 84 & 90 & 91 & 85 & 87 & 82 & 84 & 89 & 87 \\
\hline BijeloPolje & 87 & 79 & 83 & 89 & 82 & 85 & 83 & 83 & 89 & 84 \\
\hline Dobrakovo & 81 & 79 & 77 & 88 & 73 & 81 & 82 & 84 & 88 & 81 \\
\hline Average & 89 & 85 & 86 & 89 & 83 & 87 & 86 & 85 & 90 & 87 \\
\hline
\end{tabular}

\section{Discussion}

In the case of the Montenegrin part of the Lim River, it should be said that the index is not adapted to a specific purpose but is a general index for determining the overall water quality. From the results, we can clearly see how the water quality decreases downstream from the source. According 
to SWQI values and classification in the upper course of Lim, at the control stations Plav and Andrijevica, the water has excellent quality. Downstream, passing through the urban areas of Berane and BijeloPolje at the control stations Skakavac, Zaton, BijeloPolje, Dobrakovo, the water quality shifts to classes - very good and good quality. The lower water quality is a consequence of general pressures from households, production, and consumption of all forms of energy in stationary or mobile sources, industry, various mobile activities, communal and technological waste. The average values at all control stations for the research period of eight years indicate that the quality can be classified as very good (87).

In addition to the numerous advantages provided by this method, such as adaptability at the local and regional level and the combination of several parameters in one index number, this method still partially shows the ecological condition of the river. The obtained results should be considered questionable and accepted with reservation because the Serbian Water Quality Index (SWQI) method provides information on organic load but not on inorganic pollution (e.g. heavy metals). This method and the results can serve as a good basis for the general annual review of organic load in the Montenegrin part of the Lim River.

\section{Conclusion}

This paper underlines the complexity of the assessment of water quality. It confirms the importance of the Serbian Water Quality Index (SWQI) as a useful method for presenting water quality information despite its many advantages and disadvantages. In order to achieve relevant results, it is necessary to develop and apply a Water Quality Index (WQI) methodology that would include inorganic parameters. Therefore, in future research, it would be desirable to apply the Canadian Water Quality Index (CWQI) method, which uses multiple parameters and includes inorganic parameters.

Also, the results of this research according to SWQI, as expected, show that water has excellent quality in the upper course of the Montenegrin Lim River, at the control stations Plav and Andrijevica. Downstream, passing through the urban areas of Berane and BijeloPolje at the control stations Skakavac, Zaton, BijeloPolje, Dobrakovo, the water quality enters the class of very good and good quality. The results of average SWQI values at all control stations for the research period of eight years indicate that the quality in the Montenegrin part of the Lim River can be classified as very good (87). 
The quality of water at the river can become a limiting factor for development due to the negative anthropogenic impact and a threat to human health and the sustainability of natural ecosystems. Therefore, devising a strategy for the regulation, use, and protection of this essential water resource is of particular importance. Bearing in mind the current state of the river, numerous problems have been identified, which must be resolved in the coming years.

\section{References}

Babić, G., Vuković, M., Voza, D., Takić, L., \& Mladenović-Ranisavljević, I. (2019). Assessing Surface Water Quality in the Serbian Part of the Tisa River Basin. Polish Journal of Environmental Studies, 28(6).

Bharti, N.,\&Katyal, D. (2011). Water quality indices used for surface water vulnerability assessment. International journal of environmental sciences, 2(1), 154-173.

Bjelajac, D., Leščešen, I., Micić, T., \& Pantelić, M. (2013). Estimation of water quality of Sava River (Vojvodina, Serbia) in the period 2004-2011 using Serbian Water Quality Index (SWQI). Geographica Pannonica, 17(4), 91-97.

Bordalo, A. A., Teixeira, R., \& Wiebe, W. J. (2006). A water quality index applied to an international shared river basin: the case of the Douro River. Environmental management, 38(6), 910-920.

Breabăn, I. G., Ghețeu, D. \&Paiu, M. (2012).Determination of Water Quality Index of Jijia and Miletin Ponds, Bulletin UASVM Agriculture,69(2).

Breabăn, I. G., Ghețeu, D., \& Paiu, M. (2012). Determination of Water Quality Index. Bulletin UASVM Agriculture, 69, 2.

Burić, D., Ducić, V., \& Mihajlović, J. (2014). The climate of Montenegro: Modificators and types-part two. Bulletin of the Serbian geographical society, 94(1), 73-90.

Burić, M. (2010). Atlas voda Crne Gore, CANU, Podgorica.

Doderović, M., Mijanović, I., Burić, D., \& Milenković, M. (2020). Assessment of the water quality in the Morača River Basin (Montenegro) using water quality index. Glasnik Srpskog geografskog drustva, 100(2), 67-81.

Durlević, U. (2020). The Analysis of the Quality of Surface Water of Danube in the Republic of Serbia for 2018.. Zbornik radova - Geografski fakultet Univerziteta u Beogradu, 68(2), 53-70. 
Garcia, C. A. B., Silva, I. S., Mendonça, M. C. S., \& Garcia, H. L. (2018). Evaluation of Water Quality Indices: Use, Evolution and Future Perspectives. Advances in Environmental Monitoring and Assessment, 18.

Godišnji izvještaji (2010-2018). Zavod za hidrometeorologiju i seizmologiju Crne Gore. http:/ / www. meteo.co.me/ misc.php?text=57\&sektor=3

Hrvačević, S. (2004). Resursi površinskih voda Crne Gore, Podgorica. "Elektroprivreda Crne Gore" A.D. Nikšić.

Hurley, T., Sadiq, R., \& Mazumder, A. (2012). Adaptation and evaluation of the Canadian Council of Ministers of the Environment Water Quality Index (CCME WQI) for use as an effective tool to characterize drinking source water quality. Water Research, 46(11), 3544-3552.

Ismail, A., \& Robescu, D. (2017). Chemical water quality assessment of the Danube river in the lower course using water quality indices. UPB Scientific Bulletin, Series B: Chemistry and Materials Science, 79(4), 51-62.

Jakovljević, D. (2012). Serbian and Canadian water quality index of Danube river in Serbia in 2010. Journal of the Geographical Institute "Jovan Cvijić" SASA, 62(3), 1-18.

Kankal, N. C., Indurkar, M. M., Gudadhe, S. K., \& Wate, S. R. (2012). Water quality index of surface water bodies of Gujarat, India. Asian J. Exp. Sci, 26(1), 39-48.

Katyal, D. (2011). Water quality indices used for surface water vulnerability assessment. International journal of environmental sciences, 2(1).

Khan, H., Khan, A. A., \& Hall, S. (2005, June). The Canadian Water Quality Index: a tool for water resources management. In MTERM International Conference, AIT, Thailand (pp. 06-10).

Kowalkowski, T., Zbytniewski, R., Szpejna, J., \& Buszewski, B. (2006). Application of chemometrics in river water classification. Water research, 40(4), 744-752.

Kowalkowski, T., Zbytniewski, R., Szpejna, J., \& Buszewski, B. (2006). Application of chemometrics in river water classification. Water research, 40(4), 744-752.

Lumb, A., Halliwell, D., \& Sharma, T. (2006). Application of CCME Water Quality Index to monitor water quality: A case study of the Mackenzie River basin, Canada. Environmental Monitoring and assessment, 113(1), 411429. 
Milijašević-Joksimović, D., Gavrilović, B., \& Lović-Obradović, S. (2018). Application of the water quality index in the Timok River basin (Serbia). Journal of the Geographical Institute" Jovan Cvijic", SASA, 68(3), 333-344.

O'Connell, E. (2017). Towards adaptation of water resource Systems to climatic and socio-economic change. Water Resources Management, 31(10), 2965-2984.

Oregon Water Quality Index Summary Report, Water Years 1996-2005, Curtis Cude, DEQ Laboratory Division, Water Quality Monitoring Section, USA.

Radojičić, B. (2005). Vode Crne Gore, Filozofski fakultet Nikšić, Institut za geografiju, posebno izdanje, Nikšić.

Radojičić, B. (2008). Geografija Crne Gore - Prirodna osnova, DANU, Podgorica.

Radojičić, B. (2015). Crna Gora - geografski enciklopedijski leksikon, Filozofski fakultet Nikšić, Nikšić.

Shmueli, D. F. (1999). Water quality in international river basins. Political geography, 18(4), 437-476.

Singh, P. K., Tiwari, A. K., Panigarhy, B. P., \& Mahato, M. K. (2013). Water quality indices used for water resources vulnerability assessment using GIS technique: a review. Int J Earth Sci Eng, 6(6-1), 1594-1600.

Tyagi, S., Sharma, B., Singh, P., \&Dobhal, R. (2013).Water quality assessment in terms of water quality index. American Journal of water resources, 1(3), 34-38.

Veljković, N., Stanković, M. \& Milenković, S. (2000). Određivanje indeksa kvaliteta voda sliva Južne Morave primenom WQI metode [Determining water quality index of the Southern Morava basin by the application of WQI method]. In: A. Djukić (Ed.), Zaštita voda 2000 [Waters' Protection 2000]. Belgrade, Serbia: Jugoslovensko društvo za zaštitu voda.

Veljkovic, N.,\& Jovicic, M. (2007). Danube river water quality analysis using Water Quality Index methodology. In Konferencija o aktuelnim problemima koriscenja i zastite voda, 36, Tara (Serbia), 26-29 Jun 2007. Jugoslovensko drustvo za zastitu voda.

Veljković, N., Lekić, D., \& Jovičić, M. (2008). Case study of Integrated Water Quality Management: Serbian Water Quality Index. In Proceedings from XXIV Conference of the Danubian Countries on the Hydrological Forecasting and Hydrological Bases of Water Management, Slovenian National Committee for the IHP UNESCO (pp. 171-178). 